\title{
Factors responsible for high arsenic concentrations in two groundwater catchments in Taiwan
}

\author{
Sheng-Wei Wang ${ }^{a}$, Chen-Wuing Liu ${ }^{a, *}$, Cheng-Shin Jang ${ }^{b}$ \\ a Department of Bioenvironmental Systems Engineering, National Taiwan University, Taipei 106, Taiwan, ROC \\ ${ }^{\mathrm{b}}$ Research Center for Biodiversity, Academia Sinica, Taipei 116, Taiwan, ROC
}

Received 17 May 2006; accepted 8 November 2006

Editorial handling by P. McMahon

Available online 24 December 2006

\begin{abstract}
High As contents in groundwater were found in two neighboring catchments - the Chianan plain and the southern Choushui river alluvial fan in Taiwan. The groundwater quality, the redox potential and the As distribution of the Chianan plain were characterized using factor analysis, redox zoning and a geochemical program. The results were compared with those of the southern Choushui river alluvial fan. Possible As release mechanisms are also elucidated. Factors 1 and 2 of the groundwater in the Chianan plain - the salinization factor and the As enrichment factor - are similar to those in the southern Choushui river alluvial fan. However, the spatial distribution of reductive tendency in the Chianan plain is different to that in the Choushui river alluvial fan, and yields spatially distinct hydrogeochemical environments in these two neighboring areas. The reduction potential in the Chianan plain is stronger than that in the Choushui river alluvial fan. The difference between the reduction potentials in these two vicinal areas influences the concentrations of As in groundwater. The reductive dissolution of As-rich Fe oxyhydroxide is suggested to be the major mechanism for release of As to the groundwater in the Chianan plain and the Choushui river alluvial fan of Taiwan.
\end{abstract}

(C) 2006 Elsevier Ltd. All rights reserved.

\section{Introduction}

In Taiwan, the peripheral vascular disease, blackfoot disease, was first reported in the Chianan plain (Tseng et al., 1961). This disease was associated with the direct ingestion of deep well water with high As content (Tseng, 1977, 1985). In various studies, high As in well water has been associated with diabetes (Lai et al., 1994), hypertension (Chen et al., 1995)

\footnotetext{
* Corresponding author. Tel.: +88622362 6480; fax: +8862 23639557.

E-mail address: 1cw@gwater.agec.ntu.edu.tw (C.-W. Liu).
}

and cancers of the nasal cavity, lung, liver, bladder, kidney and prostate (Wu et al., 1989; Chen and Wang, 1990). At present, even though this well water is not directly ingested by most inhabitants in this region, it is still extensively provided to meet domestic, irrigation, aquacultural and industrial needs. In the aquacultural sector, in particular, high As concentrations are bioaccumulating in tilapia (Han et al., 1998; Liao and Ling, 2003). The inorganic As concentrations of the farmed fish have increased with the As concentration of pond water in this area (Huang et al., 2003), causing a potential cancer risk (Liu et al., 2005; Jang et al., 2006). 
From 1999 to 2004, the Taiwan Sugar Company undertook a groundwater quality survey at monitoring wells in the Chianan plain and its neighboring area, the southern Choushui river alluvial fan. The As concentrations of groundwater in these two areas were $0.30 \pm 0.35 \mathrm{mg} / \mathrm{L}$ and $0.12 \pm 0.14$ $\mathrm{mg} / \mathrm{L}$, respectively (Taiwan Sugar Company, 2003, 2004). In around $70 \%$ of monitoring wells in the southern Choushui river alluvial fan, and over $95 \%$ of those in the Chianan plain, the As concentrations exceeded the World Health Organization (WHO) guideline of $0.01 \mathrm{mg} / \mathrm{L}$. Moreover, the As concentration in groundwater was high in shallow $(20-70 \mathrm{~m})$ monitoring wells in the southern Choushui river alluvial fan, differing from that in deep (70-300 m) wells in the Chianan plain (Fig. 1). Liu et al. (2006) indicated that although the depth of the high As content in the groundwater in the southern Choushui river alluvial fan differed from that in the Chianan plain, the geologic ages of both areas are in the range 3-9 ka, or the Holocene transgression. The main source of As in groundwater is postulated to be geogenic deposits - especially aquitard formations of marine sequences.

a

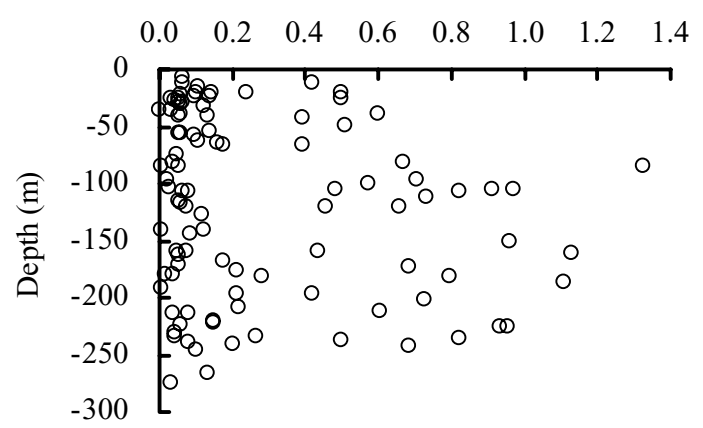

b

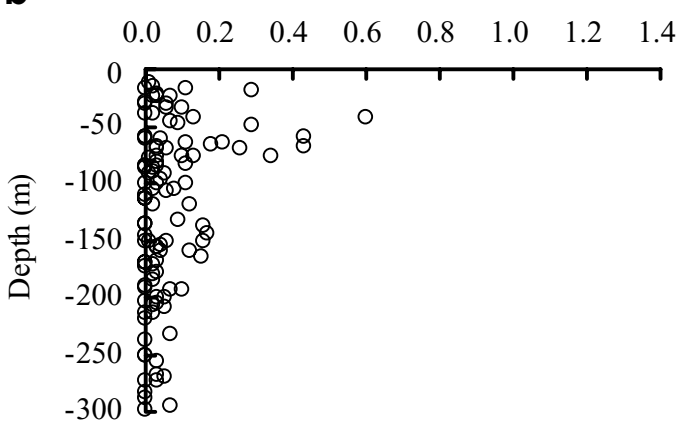

Fig. 1. Vertical distribution of As concentration in (a) the Chianan plain and (b) the southern Choushui river alluvial fan.
The two most plausible mechanisms for the release of As from sediments to groundwater are oxidation (Chatterjee et al., 1995) and reduction (Bhattacharya et al., 1997, 2004; Nickson et al., 1998). The former hypothesis suggests that As-rich Fe-sulfide may be dissolved by oxidation, driven in part by increased groundwater pumping. The latter hypothesis implies the reduction of As-rich Fe oxyhydroxides, caused by increased $\mathrm{O}_{2}$ demand possibly associated with human activities, or buried peat and organic deposits (McArthur et al., 2001). The redox conditions and processes are key in the variations of concentrations of As species in groundwater (Zheng et al., 2004; Polizzotto et al., 2005). Consequently, the redox potential may vary with depth and thus be responsible for differences between the As release mechanisms in the Chianan plain and those in the southern Choushui river alluvial fan.

Liu et al. (2003) adopted factor analysis to identify factors that govern the chemistry of groundwater in the southern Choushui river alluvial fan, and demonstrated that the hydrogeochemical process of As enrichment is the main characteristic of this groundwater. Chen and Liu (2003) used dissolved $\mathrm{O}_{2}, \mathrm{NO}_{3}^{-}$and sulfide contents, to divide the aquifers in the Choushui river alluvial fan into three redox zones along its flow path. Zone 1, the proximal fan, is oxic or $\mathrm{NO}_{3}^{-}$-reducing with $\mathrm{Eh}>0 \mathrm{mV}$. Zone 2 , the middle fan, is anoxic with detectable dissolved sulfide. Zone 3, the distal fan, is anoxic without detectable dissolved sulfide. Hence, this study characterizes the As-affected groundwater of the Chianan plain using factor analysis and redox zoning. The geochemical reactions of As in the Chianan plain and the southern Choushui river alluvial fan are calculated using PHREEQC (Parkhurst, 1995). Possible mechanisms for the release of As in these two vicinal groundwater catchments in Taiwan are proposed.

\section{Study area}

The study area includes the Chianan plain and the southern Choushui river alluvial fan (Fig. 2). These two groundwater catchments are located in the southwestern part of Taiwan and are both surrounded by the Taiwan Strait to the west and the Central Mountain to the east. The Chianan plain is bounded by the Peikang river to the north and the Ernjen river to the south, and has an area of around $2400 \mathrm{~km}^{2}$. It extends $40 \mathrm{~km}$ from east to 


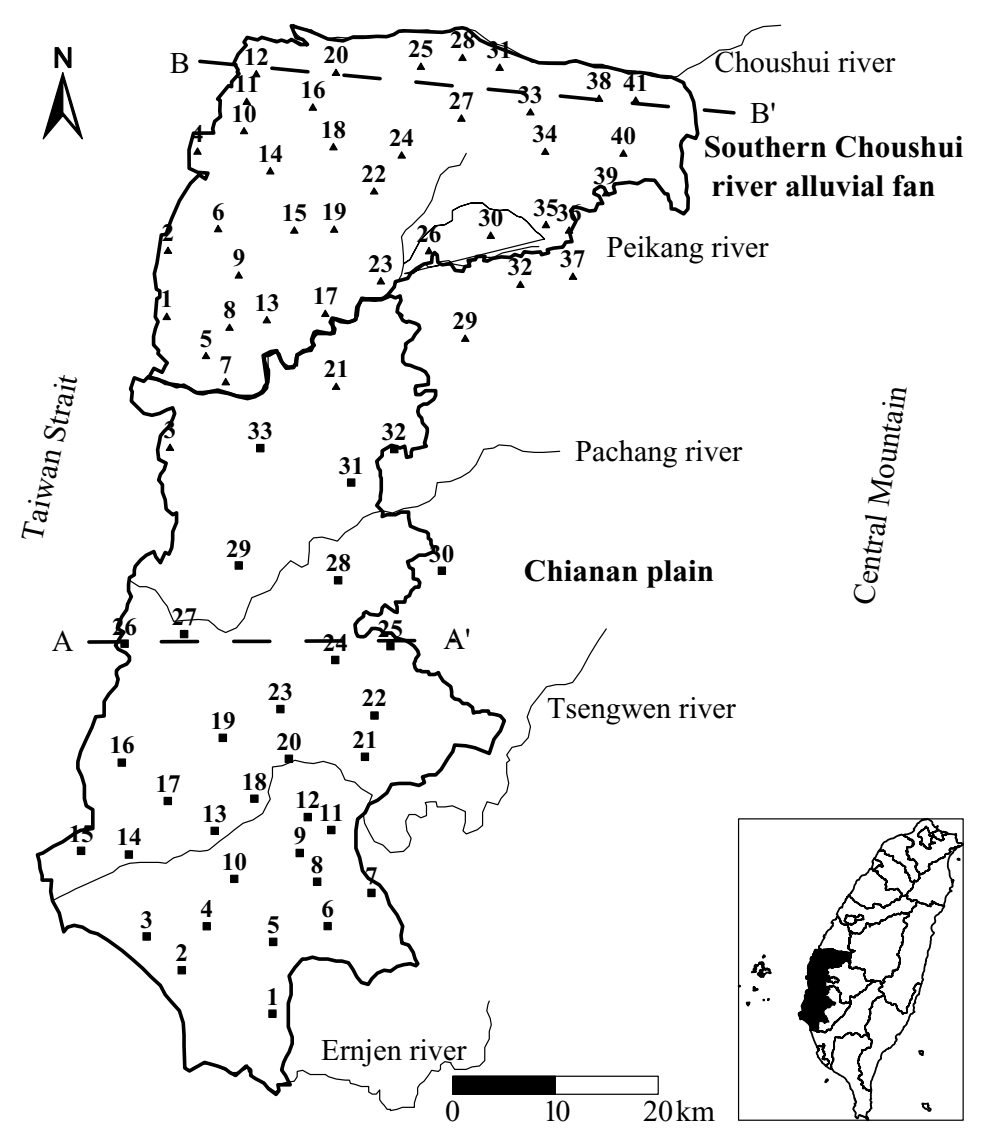

Fig. 2. Study areas. The solid triangles and solid squares represent the hydrological stations in the southern Choushui river alluvial fan and the Chianan plain, respectively. $\mathrm{A}-\mathrm{A}^{\prime}$ and $\mathrm{B}-\mathrm{B}^{\prime}$ represent the approximate location of cross sections of the Chianan plain and the southern Choushui river alluvial fan shown in Fig. 3.

west and $60 \mathrm{~km}$ from north to south. Two major rivers, the Pachang river and the Tsengwen river, flow from the NE to the west through the northern part and the southern part of the plain, respectively. The southern Choushui river alluvial fan has an area of around $1000 \mathrm{~km}^{2}$, and extends $48 \mathrm{~km}$ from east to west and $24 \mathrm{~km}$ from north to south. It is partitioned mainly into the proximal-fan, the midfan and the distal-fan areas (Central Geological Survey, 1999), and bounded by two major rivers that flow through the area, the Choushui river to the north and the Peikang river to the south.

The Chianan plain has 33 hydrological stations, including 100 monitoring wells with depths from 4 to 289 m (Taiwan Sugar Company, 2002). Fast erosion upstream and a sharp change of river gradient has caused thick muddy sediments to be deposited in the upper plain and led to poor hydraulic properties in the aquifers. Moreover, the hydrogeological profiles of the Chianan plain exhibit no obvious layer structure. However, the hydrogeological envi- ronment is divided into five aquifers. These are aquifer 1 with depths of $0-60 \mathrm{~m}$, aquifer 2 with depths of $60-140 \mathrm{~m}$, aquifer 3 with depths of $140-200 \mathrm{~m}$, aquifer 4 with depths of $200-250 \mathrm{~m}$ and aquifer 5 with depths of $250-300 \mathrm{~m}$, from top to bottom, according to the geological ages. Aquifer 1 was mostly formed in the Holocene, and the deposits in aquifers 2-5 were classified as Miocene to Pleistocene sands and silt mixed with the muddy sediments of the marine sequence (Fig. 3a).

The southern Choushui river alluvial fan has 41 hydrological stations, including 107 monitoring wells, which comprise 23 wells in aquifer 1 with depths of under $50 \mathrm{~m}, 54$ wells in aquifer 2 with depths of $60-180 \mathrm{~m}, 24$ wells in aquifer 3 with depths of 190-280 m, and wells with depths of over $280 \mathrm{~m}$ (Taiwan Sugar Company, 1997). Based on subsurface hydrogeological analysis to a depth of around $300 \mathrm{~m}$, the formation is divided into six interlayered sequences, including three marine sequences and three non-marine sequences, in the distal-fan and 
a
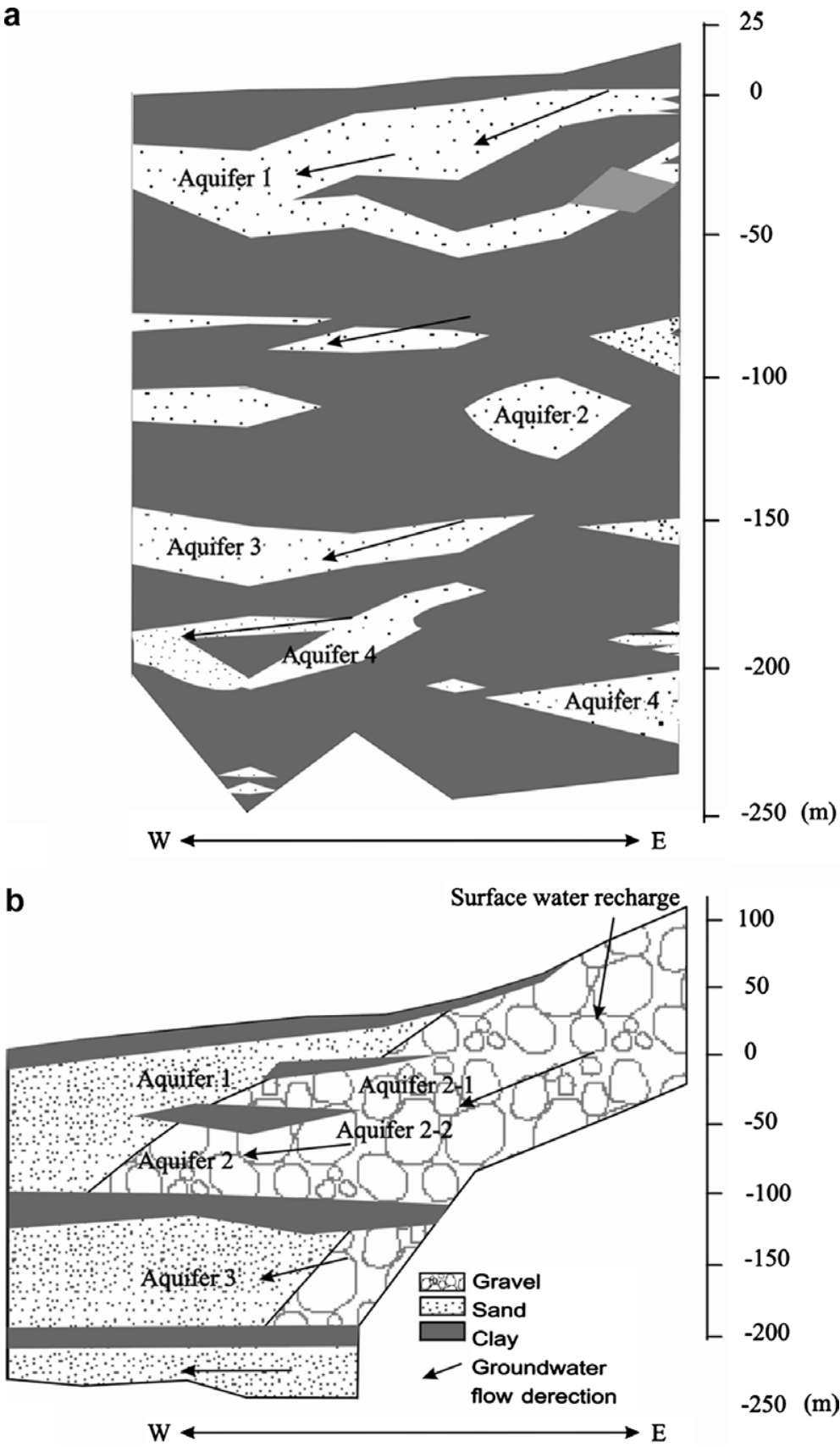

Fig. 3. Typical hydrogeological profile in the west-east direction of (a) the Chianan plain and (b) the Choushui river alluvial fan.

the mid-fan areas. The non-marine sequences of the formation, with coarse sediment, ranging from medium sand to highly permeable gravel, can typically be regarded as aquifers, whereas the marine sequences of the formation with fine sediments, can be regarded as aquitards. The hydrogeological formation of the proximal-fan, which consists entirely of gravel and sand, is considered to be an unconfined aquifer and an important groundwater recharge area (Fig. 3b). Moreover, the southern Choushui river alluvial fan was formed in the late Quaternary period. Marine sequence 1 was deposited 3-9 ka ago during the Holocene transgression; marine sequence 2 was deposited 35-50 ka ago, and marine sequence 3 was probably deposited $80-120$ ka ago during the more recent interglacial transgression (Huang, 
1996). In this work, the most complete groundwater quality data for the Chianan plain and the southern Choushui river alluvial fan were collected in 2001. The aquifers of the Chianan plain were divided into shallow $(0-70 \mathrm{~m})$, medium $(70-170 \mathrm{~m})$ and deep $(>170 \mathrm{~m})$ layers associated with different geological ages, which layering is consistent with the three well-defined aquifers of the southern Choushui river alluvial fan.

\section{Methods}

\subsection{Sampling and analysis}

The field sampling methods used follow the NIEA code W103.50B set by the Taiwan Environment Protection Agency. At least three wellbore volumes of groundwater were pumped before sampling. Dissolved $\mathrm{O}_{2}$, temperature, $\mathrm{pH}$, electrical conductivity (EC) and electrical potential (Eh) were measured in a flow-through cell every 5 min during well purging. Cell sensors were calibrated with standard solutions (all from Merck), which have $\mathrm{pH}$ $4.00, \quad 7.00$ and $10.0 ; \quad \mathrm{EC}=1410 \mu \mathrm{S} / \mathrm{cm} ; \quad \mathrm{Eh}=$ $280 \mathrm{mV}$, in the field before measuring any of these parameters (APHA, 1998). Water samples were collected only after $\mathrm{pH}$ and EC stabilized, and the fluctuations of $\mathrm{pH}$ and relative EC were less than $0.1 \%$ and 5\%, respectively. After purging, a probe (MiniSonde manufactured by HydroLab, USA), which is $5 \mathrm{~cm}$ in diameter and $70 \mathrm{~cm}$ in length, including a data logger, a circulator and five sensors for temperature, EC, pH, Eh and DO measurements, was lowered down to the screen position of the well casing and remained there for at least $10 \mathrm{~min}$ before water quality parameters were read (Chen and Liu, 2003).

Water samples for metal and other cation concentration measurements were filtered with $0.45 \mu \mathrm{m}$ glass fiber papers and acidified with $\mathrm{HNO}_{3}$ (Merck ultrapure grade) to $\mathrm{pH}$ 2. Samples for sulfide analyses were collected in narrow-mouth biochemical oxygen demand (BOD) bottles $(300 \mathrm{~mL})$ with tapered ground-glass stoppers and flared mouths. To avoid trapping or dissolving atmospheric $\mathrm{O}_{2}$, a rubber tube was extended from the pump line to the bottom of the bottle. After two or three bottle volumes of water flowed out, a stopper was placed tightly eliminating air bubbles. Samples were then kept in ice boxes and delivered to the laboratory within $24 \mathrm{~h}$. Water for total dissolved solid (TDS) determination was evaporated at $103-105{ }^{\circ} \mathrm{C}$. Total organic $\mathrm{C}$ (TOC) was measured using the high temperature combustion method (APHA, 1998). The anions $\mathrm{NO}_{3}^{-}, \mathrm{SO}_{4}^{2-}$ and $\mathrm{HS}^{-}$were determined by spectrophotometric techniques using the $\mathrm{Cd}$ reduction, turbidimetric, and methylene blue methods, respectively (APHA, 1998). Trace metal ions including Fe were measured by atomic absorption spectroscopy (AAS). A total of 15 samples including blank, spike, duplicate and check samples (standard solutions from Merck) were measured sequentially (APHA, 1998). For sulfides, the detection limit was $0.03 \mathrm{mg} / \mathrm{L}$; variances of duplicate measurements were less than $10 \%$; recoveries of check and spike samples were between $85 \%$ and $115 \%$. For $\mathrm{Fe}$, the detection limit was $0.05 \mathrm{mg} / \mathrm{L}$; variances of duplicate measurements were less than $3 \%$; recoveries of check and spike samples were between $90 \%$ and $110 \%$.

\subsection{Factor analysis and redox zoning}

Factor analysis is a multivariate statistical method, and yields the general relationship between measured chemical variables by elucidating the multivariate patterns that may help to classify the original data. It can be used to determine the geographical distribution of the resulting factors. The geochemical interpretation of factors yields insight into the main processes that may govern the distribution of hydrochemical variables. The first step of factor analysis was to standardize the raw data and make them dimensionless. The correlation coefficient matrix, eigenvalues and eigenvectors were determined to yield the covariance matrix. Then, the data were transformed into factors. Only factors with eigenvalues that exceed one are retained in this work (Reyment and Joreskog, 1993). The contribution of each factor at each monitoring well (factor scores) is computed. In this study, the 15 hydrochemical parameters of the Chianan plain, including $\mathrm{Eh}, \mathrm{pH}, \mathrm{EC}$, TDS, alkalinity (Alk), TOC, $\mathrm{NH}_{4}^{+}, \mathrm{SO}_{4}^{2-}, \mathrm{Cl}^{2-}$, $\mathrm{Ca}^{2+}, \mathrm{Mg}^{2+}, \mathrm{Na}^{+}, \mathrm{K}^{+}$, As and $\mathrm{Fe}$ concentrations, were considered to evaluate the characteristics of the groundwater by factor analysis, performed using SPSS software (SPSS Inc., 1998) metals with low concentrations $(\mathrm{Zn}, \mathrm{Cu}, \mathrm{Cd}, \mathrm{Cr}, \mathrm{Pb}, \mathrm{Ag}, \mathrm{Hg})$ and $\mathrm{NO}_{3}^{-}$, were excluded.

Stumm and Morgan (1981) addressed sequences of redox processes at $\mathrm{pH} 7$ in a natural groundwater system. Under reducing conditions, oxygenated water that enters an aquifer that is rich in organic matter first loses $\mathrm{O}_{2}$ and then $\mathrm{NO}_{3}^{-}$. Subsequently, 
$\mathrm{Fe}$ and $\mathrm{Mn}$ are dissolved, and $\mathrm{SO}_{4}^{2-}$ is reduced to sulphide. Finally, $\mathrm{CH}_{4}$ may appear in the groundwater. Chapelle et al. (1995) provided a well classification of predominant redox processes in groundwater by considering patterns of electron acceptor $\left(\mathrm{NO}_{3}^{-}\right.$and $\left.\mathrm{SO}_{4}^{2-}\right)$ consumption, intermediate product $\left(\mathrm{H}_{2}\right)$ concentrations, and final product $(\mathrm{Fe}(\mathrm{II})$, sulfide and $\mathrm{CH}_{4}$ ) production. However, due to the lack of $\mathrm{H}_{2}$ and $\mathrm{CH}_{4}$ concentration data, a simple classification of redox zones which was applied in the Choushui river alluvial fan (Chen and Liu, 2003) was adopted in the Chianan plain in this study. The definition of three redox zones in the Chianan plain were same as those in the Choushui river alluvial fan, including zone $1\left(\mathrm{Eh}>0\right.$, and $\mathrm{DO}$ or $\left.\mathrm{NO}_{3}^{-}>0.5 \mathrm{mg} / \mathrm{L}\right)$, zone 2 (Eh $<0$, and with detectable dissolved sulfide), and zone 3 (Eh $<0$, and without detectable dissolved sulfide).

\subsection{Geochemical calculations}

The geochemical program, PHREEQC, based on the database WATEQF was adopted to calculate the distribution of the aqueous species (Parkhurst, 1995). The program is based on an ion-associated aqueous program, and designed to perform a wide variety of aqueous geochemical calculations. PHREEQC can handle problems of environmental pollution, and has been used to determine which solid might be precipitating based on the saturation index (SI). The SI is defined as the logarithm of the ratio of the ion activity product (IAP) of the component ions of the solid in solution to the solubility product (Ksp) for the solid [SI $=\log \mathrm{IAP} / \mathrm{Ksp}$ ]. Negative and positive SI values represent the potential for dissolution and precipitation, respectively. In this work, the data from the monitoring wells in all layers and redox zones were collected to calculate chemical speciation and mineral saturation of groundwater in the Chianan plain and the southern Choushui river alluvial fan. Seventeen terms from each monitoring well were used in the calculation. They were $\mathrm{pH}, \mathrm{Eh}$, temperature, DO, Alk, $\mathrm{SO}_{4}^{2-}$, $\mathrm{Cl}^{-}, \mathrm{Ca}^{2+}, \mathrm{Mg}^{2+}, \mathrm{Na}^{+}, \mathrm{K}^{+}$, As, $\mathrm{Fe}, \mathrm{Mn}, \mathrm{NH}_{4}^{-}$, $\mathrm{NO}_{3}^{-}$and $\mathrm{HS}^{-}$(Table 1).

\section{Results and discussion}

\subsection{Factor analysis}

Table 2 presents the correlation coefficients of 15 hydrochemical parameters of the Chianan plain.
The correlations between As and other parameters are weak, especially the Fe $(R=-0.055, p>0.05)$ and $\mathrm{SO}_{4}^{2-}(R=-0.218, p>0.05)$ which associate with As release to groundwater. Table 3 presents the eigenvalues of the first three factors, their percentage of variance and cumulative percentage of variance. It reveals that the eigenvalues of the three factors, which exceed one, explain $77.52 \%$ of the total variance in the data set. Table 4 presents the loading of the varimax rotation factor matrix for the threefactor model. The terms, "strong", "moderate" and "weak" as applied to factor loadings, refer to absolute loading values of $>0.75,0.75-0.5$ and $0.5-$ 0.3 , respectively. This study selected absolute factor loadings of over 0.5 to elucidate the relationships between the factors and the hydrochemical data. A factor score associated with each monitoring well was determined. They were plotted to illustrate the spatial characteristics of the quality of groundwater in the Chianan plain.

Factor 1, which has strong positive loadings on EC, TDS, $\mathrm{SO}_{4}^{2-}, \mathrm{Cl}^{-}, \mathrm{Ca}^{2+}, \mathrm{Mg}^{2+}, \mathrm{Na}^{+}$and $\mathrm{K}^{+}$, and moderate positive loadings on $\mathrm{NH}_{4}^{+}$, explains $50.34 \%$ of the total variance. The strong positive terms are the dominant solutes in seawater. Thus, factor 1 is called the salinization factor. The presence of $\mathrm{NH}_{4}^{+}$demonstrated the reducing environment in this sedimentary basin, in which the hydraulic properties of the aquifers are poor. Over pumping has led to severe groundwater drawdown (Lambrakis et al., 1996) and the intrusion of seawater (Petalas and Lambrakis, 2006). Groundwater levels of the monitoring wells in these two areas are generally below sea level, especially in the coastal region. Fig. 4a shows the spatial distribution of the scores of factor 1 with different depths. High values represent high-salinization regions. The most critical district of groundwater salinization is the SW region of the shallow layer, which is the major area for producing salt in Taiwan. The annual amount of salt produced there is about $60 \%$ of the total amount produced in Taiwan. Accordingly, seawater intrusion may not be the only source of salinization of the shallow layer, the infiltration from salt fields being partially responsible for the salinization.

Factor 2, which has strong positive loadings on Alk and TOC, moderate positive loadings on As and moderate negative loadings on Eh, explains $18.62 \%$ of the total variance. Its relationship with Alk, TOC and As is regarded as involving the association of inorganic/organic $\mathrm{C}$ with As, while the 
Table 1

Physico-chemical parameters and major ionic constituents in groundwater of shallow, medium and deep layers, and their corresponding redox zonations of the Chianan plain and the southern Choushui river alluvial fan

\begin{tabular}{|c|c|c|c|c|c|c|c|c|c|c|c|c|c|c|c|c|c|c|}
\hline \multirow{3}{*}{$\begin{array}{l}\text { Area } \\
\text { Layer } \\
\text { Redox zone }\end{array}$} & \multicolumn{9}{|c|}{ Chianan plain } & \multicolumn{9}{|c|}{ Southern Choushui river alluvial fan } \\
\hline & \multicolumn{3}{|c|}{ Shallow } & \multicolumn{3}{|c|}{ Medium } & \multicolumn{3}{|l|}{ Deep } & \multicolumn{3}{|c|}{ Shallow } & \multicolumn{3}{|c|}{ Medium } & \multicolumn{3}{|l|}{ Deep } \\
\hline & 2 & 2 & 3 & 2 & 2 & 2 & 2 & 2 & 3 & 1 & 2 & 3 & 1 & 2 & 3 & 1 & 2 & 3 \\
\hline Station no. & 28 & 21 & 12 & 20 & 19 & 27 & 28 & 30 & 16 & 41 & 27 & 6 & 38 & 26 & 6 & 41 & 23 & 6 \\
\hline $\mathrm{pH}$ & 7.6 & 7.7 & 7.4 & 7.8 & 7.3 & 7.8 & 7.6 & 6.9 & 7.6 & 7.6 & 7.4 & 8.0 & 7.5 & 7.7 & 8.0 & 7.5 & 8.0 & 8.1 \\
\hline Eh (mV) & -142 & -294 & -173 & -259 & -299 & -83 & -302 & -206 & -115 & 282 & -151 & -226 & -3 & -145 & -160 & 41 & -179 & -160 \\
\hline Temp $\left({ }^{\circ} \mathrm{C}\right)$ & 25.2 & 26.0 & 26.1 & 26.9 & 26.3 & 27.0 & 29.1 & 28.3 & 28.6 & 24.5 & 24.8 & 25.4 & 23.8 & 25.0 & 26.4 & 23.4 & 25.0 & 28.0 \\
\hline DO (mg/L) & 0.2 & 0.2 & 0.3 & 0.3 & 0.3 & 0.3 & 0.2 & 0.2 & 0.3 & 4.6 & 0.2 & 0.4 & 4.5 & 0.2 & 0.1 & 0.3 & 0.1 & 0.1 \\
\hline Alk (mg/L) & 350 & 430 & 875 & 460 & 405 & 620 & 470 & 370 & 685 & 250 & 425 & 415 & 275 & 205 & 235 & 255 & 170 & 220 \\
\hline $\mathrm{SO}_{4}^{2-}(\mathrm{mg} / \mathrm{L})$ & 90 & 206 & 2421 & 13.7 & 15.3 & 5.8 & 5.9 & 5.8 & 17.3 & 116.0 & 157.0 & 105.0 & 133.0 & ND & ND & 137.0 & 1.9 & 7.7 \\
\hline $\mathrm{Cl}(\mathrm{mg} / \mathrm{L})$ & 25 & 16,472 & 19,780 & 17 & 8245 & 249 & 218 & 1011 & 1190 & 15 & 37 & 63 & 13 & 9 & 10 & 32 & 11 & 19 \\
\hline $\mathrm{Ca}(\mathrm{mg} / \mathrm{L})$ & 65.3 & 101.0 & 663.0 & 14.9 & 57.0 & 12.5 & 30.6 & 75.2 & 22.7 & 108.0 & 155.0 & 49.1 & 121.0 & 30.1 & 37.1 & 140.0 & 30.1 & 39.1 \\
\hline $\mathrm{Mg}(\mathrm{mg} / \mathrm{L})$ & 39.4 & 293.7 & 318.4 & 8.3 & 104.7 & 12.9 & 15.9 & 45.3 & 34.7 & 23.7 & 37.7 & 38.3 & 29.2 & 7.3 & 6.1 & 19.0 & 6.1 & 6.7 \\
\hline $\mathrm{Na}(\mathrm{mg} / \mathrm{L})$ & 44 & 9526 & 11815 & 153 & 4253 & 417 & 229 & 657 & 932 & 13 & 30 & 125 & 12 & 45 & 55 & 15 & 39 & 55 \\
\hline $\mathrm{K}(\mathrm{mg} / \mathrm{L})$ & 23.8 & 409.6 & 473.1 & 26.0 & 103.9 & 39.8 & 28.9 & 19.1 & 37.6 & 1.6 & 2.4 & 24.2 & 2.0 & 0.8 & 1.2 & 0.8 & 0.4 & 1.2 \\
\hline As (mg/L) & 0.1 & 0.2 & 0.3 & 0.0 & 0.1 & 0.6 & 0.1 & 0.9 & 1.0 & ND & 0.0 & 0.6 & ND & 0.1 & 0.1 & ND & 0.0 & 0.0 \\
\hline $\mathrm{Fe}(\mathrm{mg} / \mathrm{L})$ & 1.9 & 0.7 & 24.4 & 0.2 & 1.1 & 0.9 & 0.9 & 3.2 & 4.5 & 0.2 & 5.0 & 0.6 & ND & 4.1 & 0.4 & 0.2 & 0.4 & 0.1 \\
\hline Mn (mg/L) & 0.2 & 0.1 & 1.5 & 0.3 & 0.5 & 0.0 & 0.4 & 0.1 & 0.2 & ND & 0.2 & 0.3 & ND & 0.3 & 0.1 & 0.2 & 0.2 & 0.3 \\
\hline $\mathrm{NH}_{4}^{+}(\mathrm{mg} / \mathrm{L})$ & 2.8 & 34.5 & 24.8 & 1.3 & 37.6 & 12.6 & 5.7 & 13.0 & 15.9 & 0.1 & 3.3 & 5.2 & 0.1 & 2.0 & 0.7 & 0.1 & 0.5 & 0.7 \\
\hline $\mathrm{NO}_{3}^{-}(\mathrm{mg} / \mathrm{L})$ & $\mathrm{ND}^{\mathrm{a}}$ & ND & ND & ND & 0.11 & 0.09 & ND & ND & 0.22 & 7.05 & 0.10 & 0.08 & 8.02 & 0.08 & 0.09 & 10.40 & ND & 0.08 \\
\hline $\mathrm{HS}^{-}(\mathrm{mg} / \mathrm{L})$ & 0.04 & 0.04 & ND & 0.04 & 0.06 & 0.07 & 0.04 & 0.07 & ND & 0.06 & 0.04 & ND & 0.06 & 0.04 & ND & 0.04 & 0.06 & ND \\
\hline
\end{tabular}

${ }^{\mathrm{a}}$ Non detectable. 


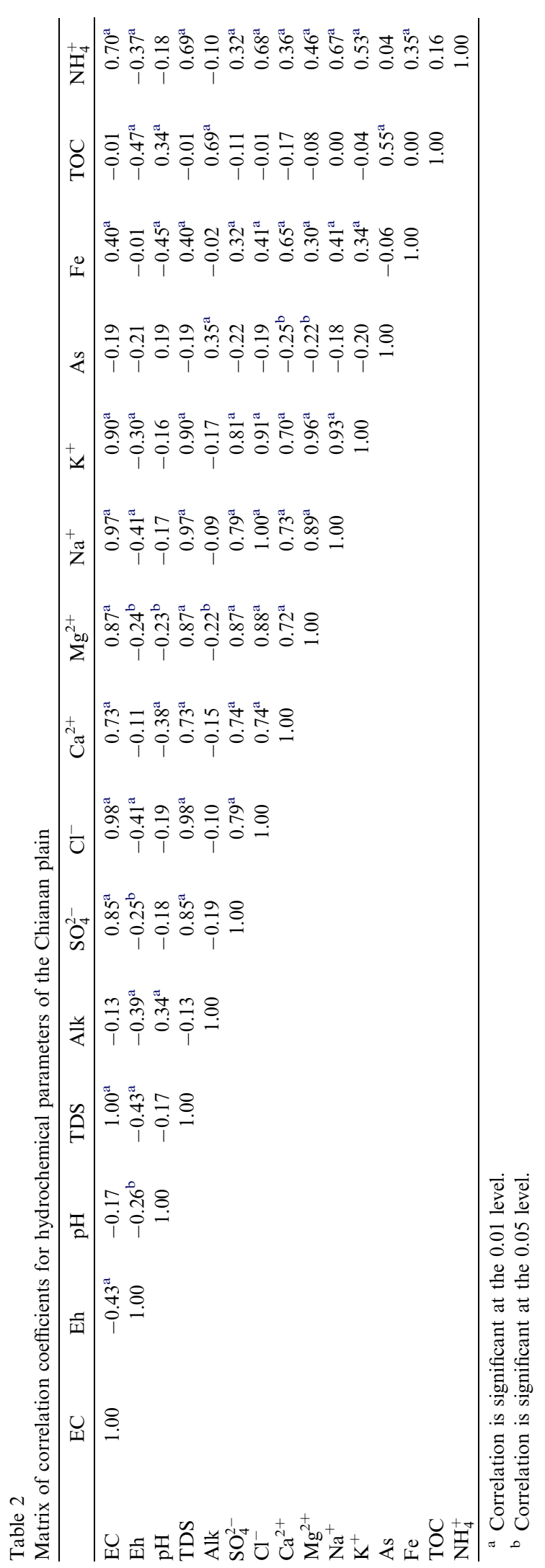

Table 3

Eigenvalues, percentage of variance, and cumulative percentage of variance of the first three factors, for which the eigenvalues exceed one, in the factor analysis

\begin{tabular}{llll}
\hline Factor & Eigenvalue & $\begin{array}{l}\text { Percentage of } \\
\text { variance }\end{array}$ & $\begin{array}{l}\text { Cumulative percentage } \\
\text { of variance }\end{array}$ \\
\hline 1 & 7.55 & 50.34 & 50.34 \\
2 & 2.79 & 18.62 & 68.96 \\
3 & 1.28 & 8.56 & 77.52 \\
\hline
\end{tabular}

Table 4

Loadings for varimax-rotated factor matrix in three-factor model

\begin{tabular}{lrrr}
\hline Variable & Factor 1 & Factor 2 & Factor 3 \\
\hline $\mathrm{EC}$ & $\mathbf{0 . 8 5}$ & 0.02 & 0.14 \\
$\mathrm{Eh}$ & -0.42 & $-\mathbf{0 . 6 7}$ & 0.15 \\
$\mathrm{pH}$ & -0.09 & 0.37 & $-\mathbf{0 . 7 9}$ \\
$\mathrm{TDS}$ & $\mathbf{0 . 9 8}$ & 0.02 & 0.09 \\
$\mathrm{Alk}$ & -0.14 & $\mathbf{0 . 8 2}$ & -0.07 \\
$\mathrm{SO}_{4}^{2-}$ & $\mathbf{0 . 8 9}$ & -0.12 & -0.05 \\
$\mathrm{Cl}^{-}$ & $\mathbf{0 . 9 7}$ & 0.04 & 0.13 \\
$\mathrm{Ca}^{2+}$ & $\mathbf{0 . 7 9}$ & -0.18 & 0.23 \\
$\mathrm{Mg}^{2+}$ & $\mathbf{0 . 9 3}$ & -0.12 & 0.01 \\
$\mathrm{Na}^{+}$ & $\mathbf{0 . 9 7}$ & 0.05 & 0.10 \\
$\mathrm{~K}^{+}$ & $\mathbf{0 . 9 5}$ & -0.06 & 0.02 \\
$\mathrm{As}$ & -0.19 & $\mathbf{0 . 6 8}$ & 0.07 \\
$\mathrm{Fe}$ & 0.18 & 0.40 & $\mathbf{0 . 7 2}$ \\
$\mathrm{TOC}^{+}$ & 0.00 & $\mathbf{0 . 9 1}$ & 0.09 \\
$\mathrm{NH}$ & $\mathbf{0 . 6 1}$ & 0.18 & 0.38 \\
\hline $\mathrm{Absolyte}$ & &
\end{tabular}

Absolute factor loadings of over 0.5 are shown in bold typeface.

negative loading of Eh is associated with the reducing condition of this groundwater. Therefore, factor 2 is called the As enrichment factor. The presence of dissolved carbonate may influence the adsorption of trace metals by competing for sites on mineral surfaces, forming carbonate complexes that can either enhance or suppress adsorption, and forming precipitates (Villalobos et al., 2001). The mobilization of adsorbed As with dissolved carbonate has been proposed to be one of the major causes of high levels of As in groundwater (Appelo et al., 2002; Anawar et al., 2003, 2004; Garcia-Sanchez et al., 2005). Harvey et al. (2002) indicated that the dissolved organic C (DOC) and dissolved inorganic C (DIC) in groundwater in Bangladesh was positively correlated with As content, and concluded that the mobility of As is closely related to the recent inflow of $\mathrm{C}$ through either displacement by carbonate or the organic $\mathrm{C}$-driven reduction of $\mathrm{Fe}$ oxide.

Fig. $4 \mathrm{~b}$ shows the spatial distribution of the scores of factor 2 at different depths. High values represent the region with high As content. The potential for As enrichment increases with depth. The most likely area for As enrichment is the SW 

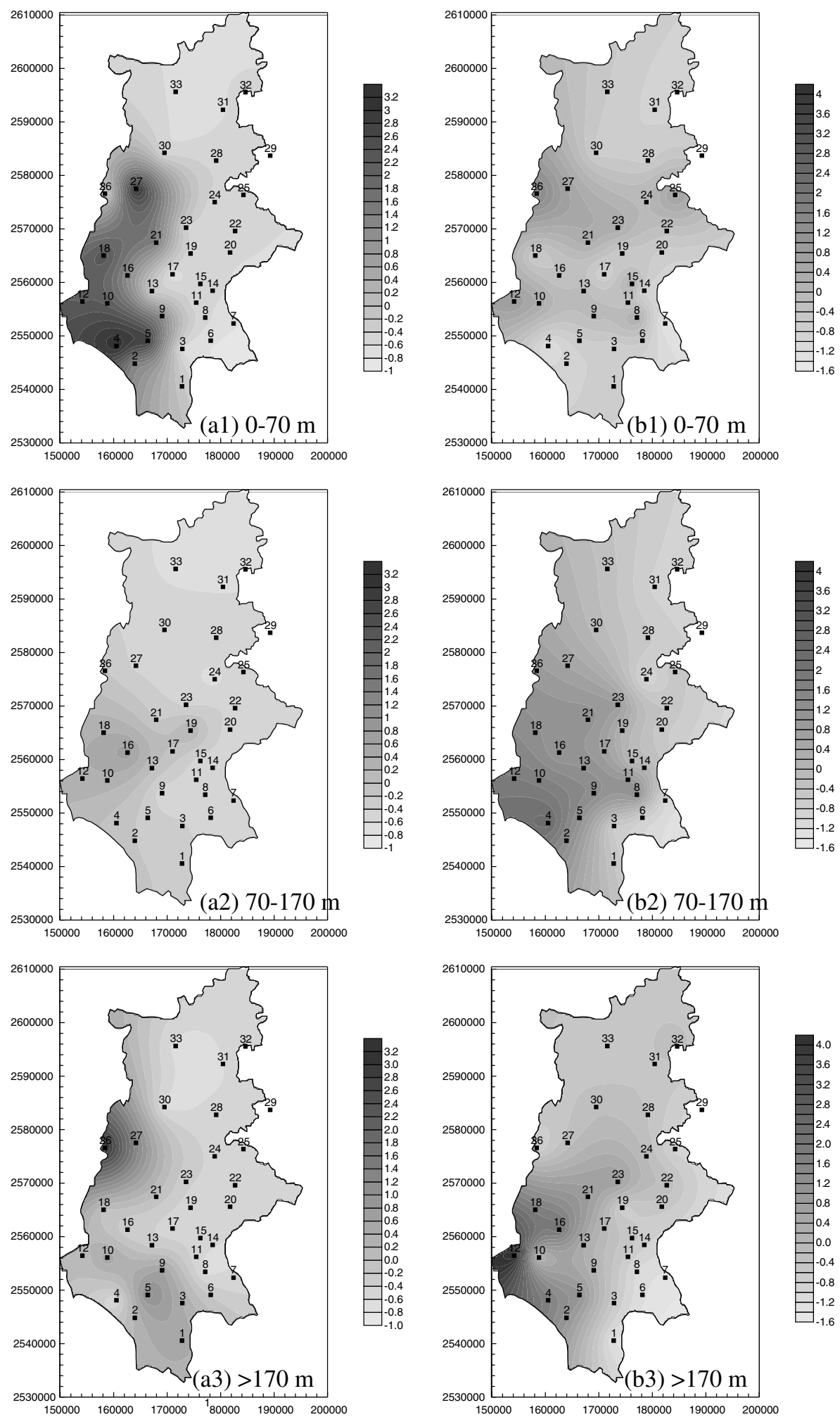

Fig. 4. Spatial distributions of the scores of (a) factor 1 (salinization factor) and (b) factor 2 (As enrichment factor) at different depths beneath the Chianan plain. 
of the Chianan plain. The As enrichment factor represents the potential for As enrichment, which is based on well correlation between As, Alk and TOC. Factor 3, which has strong positive and negative loadings on $\mathrm{Fe}$ and $\mathrm{pH}$, respectively, explains $8.56 \%$ of the total variance. This result is consistent with the decrease in $\mathrm{pH}$ as dissolved $\mathrm{Fe}(\mathrm{II})$ increases (Herbel and Fendorf, 2006). Furthermore, factors 1 and 2 of the Chianan plain are similar to those of the southern Choushui river alluvial fan (Liu et al., 2003).

\subsection{Redox zoning}

Fig. 5 shows the distribution of redox zones at different depths of the Chianan plain and the Choushui river alluvial fan, reproduced from Chen and Liu (2003) and Jang and Liu (2005). Zone 1 is not found in three depths of the Chianan plain. The lack of zone 1 in the Chianan plain indicates that the reduction potential in this area exceeds that in the Choushui river alluvial fan. The reduction potential tends to increase from the coastal area to the mountainous area in all three layers, although the increases are not very clear in the shallow layer. The special redox zonations are the reverse of those in the Choushui river alluvial fan (Chen and Liu, 2003). The reductive tendency of the Choushui river alluvial fan increases from the proximal-fan, the mountainous area, toward the distal-fan, the coastal area. However, regional groundwater flow moves from the mountainous area toward the coastal area in these two vicinal regions.

Surface water readily infiltrates to the proximalfan unconfined aquifer of the Choushui river alluvial fan, whereas the thick organic-rich clay found in the confined aquifer of the Chianan plain prevents much surface water recharge (Fig. 3). The indistinct layering structures results in the hydraulic conductivity and velocity of groundwater flow of the Chianan plain being lower than those of the Choushui river alluvial fan. Baedecker and Back $(1979 a, b)$ noted that the decomposition of organicrich material produces an organic-rich leachate that contains such chemicals as volatile fatty acids and fulvic acid-like compounds. This infiltrating water slowly moves to an anoxic aquifer of the Chianan plain. Meanwhile, in the Choushui river alluvial fan, the surface water quickly replenishes an oxic aquifer. Therefore, the various hydrogeochemical characteristics of mixing between the surface water and groundwater are primarily responsible for the distinct spatial distributions of redox zones of these two neighboring areas.

The concentration of dissolved As is governed primarily by sorption and precipitation (Bauer and Blodau, 2006). The oxidation state of As and the presence of inorganic and organic solutes affect the extent of the adsorption of As onto Fe oxyhydroxides (Wilkie and Hering, 1996; Hering et al., 1997). Under sufficiently reducing conditions, the precipitation of As sulfides, such as arsenopyrite, can control aqueous As levels (Vink, 1996; Nicholas et al., 2003). The redox reactions, involving As, Fe and $\mathrm{S}$, appear to control the fate and transport of As in As-enriched environments (Kuhn and Sigg, 1993; Spliethoff et al., 1995). Therefore, the various spatial distributions of redox zones between these two neighboring areas may result in different mechanisms of As release to groundwater.

\subsection{Geochemical calculations}

Tables 5 and 6 present the ratios of the contents of particular chemical species to total contents and the resulting saturation indices of various minerals, respectively. The major $\mathrm{C}$-containing species in these two reducing groundwaters are $\mathrm{HCO}_{3}^{-}$and $\mathrm{H}_{2} \mathrm{CO}_{3}$. The proportion of $\mathrm{HCO}_{3}^{-}$increases with depth and the redox zones. The alkalinities of these two catchments generally exceed those of other regions in Taiwan, because the groundwater contains a large amount of $\mathrm{HCO}_{3}^{-}$. The mild potential for precipitation of calcite and dolomite in these two areas are similar to those in Bangladesh (Swartz et al., 2004), and are associated with limestone deposits. However, saturated $\mathrm{O}_{2}$ in groundwater may react with reduced substances in the aquifer sediment, such as organic matter or the Fe-bearing mineral, pyrite. The product may induce precipitation of carbonate minerals (Chapelle et al., 1987), such as magnesite. According to Tables 5 and 6, arsenite, especially in the form of $\mathrm{H}_{3} \mathrm{AsO}_{3}$, is the dominant As species in these two groundwaters. Due to the As concentration of the groundwater being undetectable, no As species were calculated in redox zone 1 of the three layers in the southern Choushui river alluvial fan. $\mathrm{HAsO}_{4}^{2-}$ is the predominant As species in station 27 of the medium layer and station 16 of the deep layer in the Chianan plain, because the Eh $(-83$ and $-115 \mathrm{mV})$ of these two monitoring wells is relatively high. The As oxide minerals, such as arsenolite and claudetite, 

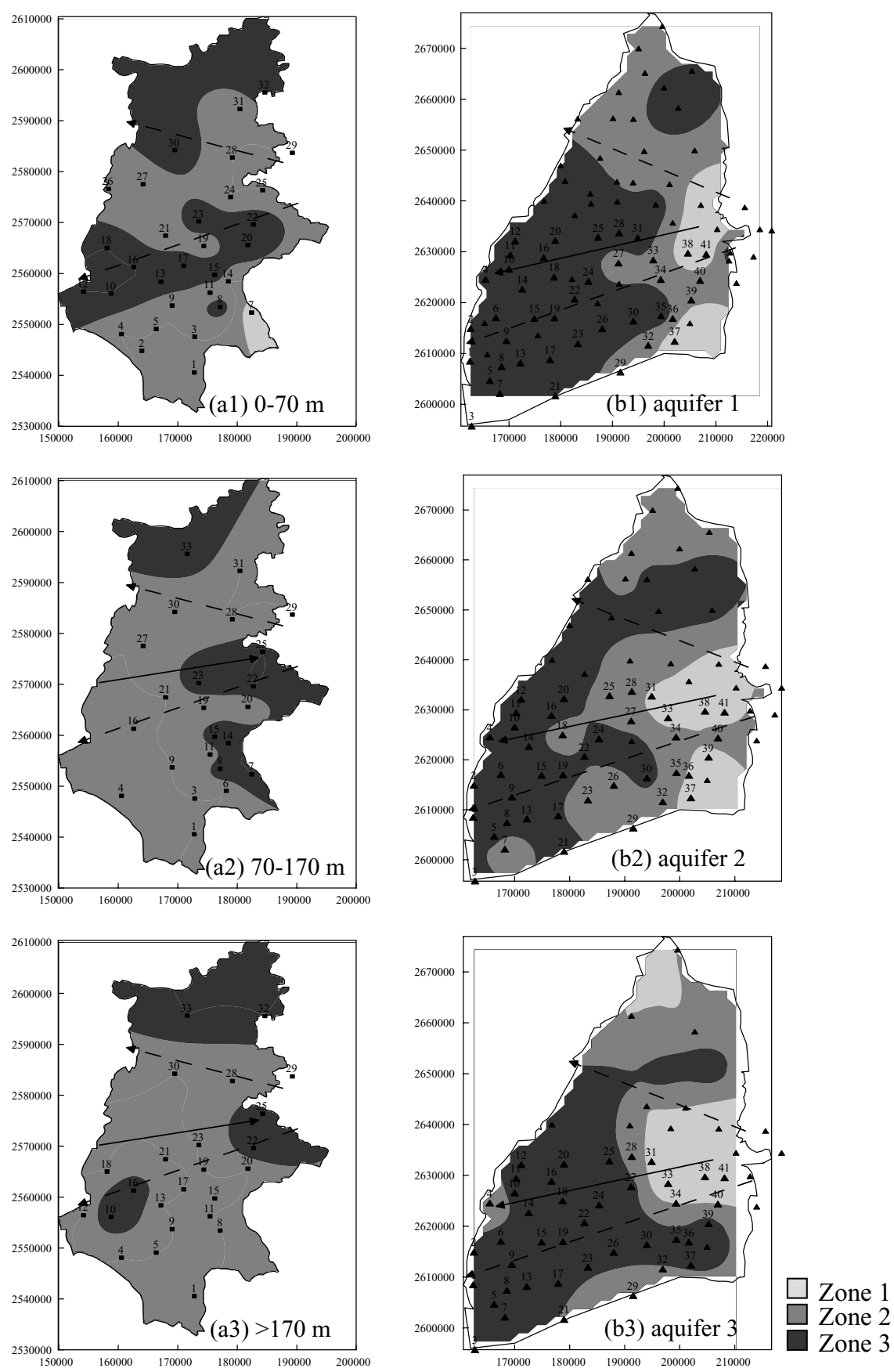

Fig. 5. Distribution of redox zones at different depths of (a) the Chianan plain and (b) the Choushui river alluvial fan. Zone 1 represents $\mathrm{Eh}>0 \mathrm{mV}$, DO $>0.5 \mathrm{mg} / \mathrm{L}$ or $\mathrm{NO}_{3}^{-}>0.5 \mathrm{mg} / \mathrm{L}$; zone 2 represents $\mathrm{Eh}<0 \mathrm{mV}$ with detectable dissolved sulfide concentration; zone 3 represents $\mathrm{Eh}<0 \mathrm{mV}$ without detectable dissolved sulfide concentration. The solid line and broken line arrows denote the sequence of the redox zonation and the direction of groundwater flow, respectively.

may dissolve, whereas the As sulfide minerals, such as orpiment and realgar, may precipitate and dissolve, respectively. Kim et al. (2000) stated that the carbonation of As sulfide minerals, such as orpiment and realgar, is an important process in the leaching of As into groundwater under anaerobic conditions.

Only the well of zone 1 of the shallow layer in the southern Choushui river alluvial fan with the highest Eh value, has $73.9 \% \mathrm{Fe}(\mathrm{OH})^{2+}$ as the primary $\mathrm{Fe}$ 
Table 5

Ratio of amount of different chemical species contents to the total elemental content of groundwater in shallow, medium and deep layers, and their corresponding redox zonations, modeled using PHREEQC

\begin{tabular}{|c|c|c|c|c|c|c|c|c|c|c|c|c|c|c|c|c|c|c|}
\hline \multirow{3}{*}{$\begin{array}{l}\text { Area } \\
\text { Layer } \\
\text { Redox zone }\end{array}$} & \multicolumn{9}{|c|}{ Chianan plain } & \multicolumn{9}{|c|}{$\underline{\text { Southern Choushui river alluvial fan }}$} \\
\hline & \multicolumn{3}{|c|}{ Shallow } & \multicolumn{3}{|c|}{ Medium } & \multicolumn{3}{|c|}{ Deep } & \multicolumn{3}{|c|}{ Shallow } & \multicolumn{2}{|c|}{ Medium } & \multicolumn{4}{|c|}{ Deep } \\
\hline & 2 & 2 & 3 & 2 & 2 & 2 & 2 & 2 & 3 & 1 & 2 & 3 & 1 & 2 & 3 & 1 & 2 & 3 \\
\hline Station no. & 28 & 21 & 12 & 20 & 19 & 27 & 28 & 30 & 16 & 41 & 27 & 6 & 38 & 26 & 6 & 41 & 23 & 6 \\
\hline \multicolumn{19}{|l|}{ C } \\
\hline $\mathrm{HCO}_{3}^{-}$ & 91.9 & 81.5 & 75.0 & 95.4 & 85.2 & 95.3 & 93.1 & 80.1 & 92.6 & 91.1 & 88.4 & 94.5 & 90.0 & 93.9 & 95.5 & 90.1 & 95.7 & 95.4 \\
\hline $\mathrm{H}_{2} \mathrm{CO}_{3}$ & 5.0 & 2.4 & 4.2 & 3.2 & 7.6 & 2.6 & 4.9 & 16.7 & 4.5 & 5.1 & 7.0 & 1.8 & 6.1 & 3.7 & 1.9 & 5.8 & 2.2 & 1.6 \\
\hline \multicolumn{19}{|l|}{ As } \\
\hline $\mathrm{H}_{3} \mathrm{AsO}_{3}$ & 97.3 & 94.0 & 95.9 & 96.4 & 98.3 & 4.0 & 97.6 & 99.4 & 6.1 & $-^{\mathrm{a}}$ & 98.5 & 93.9 & - & 96.1 & 83.7 & - & 94.4 & 56.0 \\
\hline $\mathrm{H}_{2} \mathrm{AsO}_{3}^{-}$ & 2.1 & 6.0 & 3.5 & 3.6 & 1.7 & 0.2 & 2.4 & 0.6 & 1.6 & - & 1.5 & 6.0 & & 2.8 & 5.0 & & 4.9 & 4.1 \\
\hline $\mathrm{HAsO}_{4}^{2-}$ & 0.4 & 0.0 & 0.5 & 0.0 & 0.0 & 88.7 & 0.0 & 0.0 & 38.1 & - & 0.0 & 0.1 & - & 1.0 & 10.6 & - & 0.7 & 37.7 \\
\hline $\mathrm{H}_{2} \mathrm{AsO}_{4}^{-}$ & 0.1 & 0.0 & 0.0 & 0.0 & 0.0 & 7.0 & 0.0 & 0.0 & 4.2 & - & 0.0 & 0.0 & - & 0.1 & 0.7 & - & 0.1 & 2.2 \\
\hline \multicolumn{19}{|l|}{$\mathrm{Fe}$} \\
\hline $\mathrm{Fe}^{2+}$ & 89.1 & 99.3 & 97.8 & 91.3 & 99.0 & 91.8 & 93.0 & 96.6 & 93.8 & 0.7 & 87.2 & 86.7 & - & 95.7 & 93.6 & 87.8 & 94.6 & 92.1 \\
\hline $\mathrm{Fe}(\mathrm{OH})^{2+}$ & 0.0 & 0.0 & 0.0 & 0.0 & 0.0 & 0.0 & 0.0 & 0.0 & 0.0 & 73.9 & 0.0 & 0.0 & - & 0.0 & 0.0 & 0.0 & 0.0 & 0.0 \\
\hline \multicolumn{19}{|l|}{ S } \\
\hline $\mathrm{SO}_{4}^{2-}$ & 79.4 & 51.1 & 40.8 & 91.0 & 69.6 & 86.4 & 85.7 & 76.6 & 84.1 & 77.0 & 72.8 & 82.4 & 75.6 & - & - & 75.3 & 81.2 & 87.2 \\
\hline $\mathrm{CaSO}_{4}$ & 10.7 & 2.4 & 11.6 & 3.1 & 2.0 & 1.8 & 5.2 & 7.5 & 2.1 & 17.4 & 19.6 & 7.5 & 18.1 & - & - & 20.6 & 7.5 & 9.7 \\
\hline
\end{tabular}

${ }^{\text {a }}$ No data.

species. Ferrous iron is typically the primary Fe species in groundwater under reducing conditions. The Fe oxides, including hematite and magnetite, may be present in the solid phase in these two groundwaters. However, the Fe oxyhydroxide, goethite, may be partially present in aqueous and solid phases in the Chianan plain and the southern Choushui river alluvial fan, respectively. Arsenic-rich Fe oxyhydroxide is dissolved under reducing conditions in the subsurface. Under oxidizing conditions, and in the presence of $\mathrm{Fe}$, most of the inorganic species of As are retained in the solid phase through interaction with Fe oxyhydroxide coatings on soil particles. The establishment of reducing conditions in such environments can lead to the dissolution of Fe oxyhydroxide coatings. The fermentation of peat in the subsurface releases organic acids (such as acetate) and thus drives the reductive dissolution of $\mathrm{Fe}$ oxyhydroxide, releasing arsenite, arsenate and $\mathrm{Fe}(\mathrm{II})$ to groundwater (McArthur et al., 2001; Nickson et al., 2000). Moreover, $\mathrm{SO}_{4}^{2-}$ is the primary $\mathrm{S}$ species in these two groundwaters. The SI values of the sulfate minerals are, however, all negative and close to 0 , suggesting that the rise in the $\mathrm{SO}_{4}^{2-}$ content in the groundwater may be caused not only by the intrusion of seawater, but also partially by the dissolution of sulfate minerals. The SI values of the pyrite of these two areas are all positive. The oxidation of As-bearing pyrite minerals may mobilize As. Insoluble As-bearing pyrite or arsenopyrite (FeAsS) are rapidly oxidized when they are exposed to the atmosphere, releasing soluble arsenite, $\mathrm{SO}_{4}^{2-}$ and $\mathrm{Fe}(\mathrm{II})$ (Mandal et al., 1996). The dissolution of these As-containing minerals depends highly on the availability of $\mathrm{O}_{2}$ and the rate of oxidation of sulfide (Loeppert, 1997).

\subsection{Possible release mechanisms of As}

According to the factor analysis, As enrichment is the main characteristic of groundwater in these two catchments. High As concentrations of groundwater occur in the lowermost $(>170 \mathrm{~m})$ and uppermost (aquifer 1) aquifers of the Chianan plain and the Choushui river alluvial fan, respectively (Fig. 6). Additionally, As concentrations of groundwater in all layers of the Chianan plain are higher than those in the Choushui river alluvial fan. Figs. 5 and 6 show that zones 2 and 3 are the primary areas where high As occurred, and indicate that the reducing condition of the groundwater affected the elevated As concentration. In the Chianan plain, the DO and $\mathrm{NO}_{3}^{-}$concentrations of all groundwaters are mostly less than $0.5 \mathrm{mg} / \mathrm{L}$, and the $\mathrm{Fe}(\mathrm{II})$ concentrations generally increase along the flow path of the groundwater, especially in the lowermost aquifer $(>170 \mathrm{~m})$ (Table 1).

In the southern Choushui river alluvial fan, high As concentrations occur in the distal-fan and the mid-fan areas (zones 2 and 3). The distribution of 


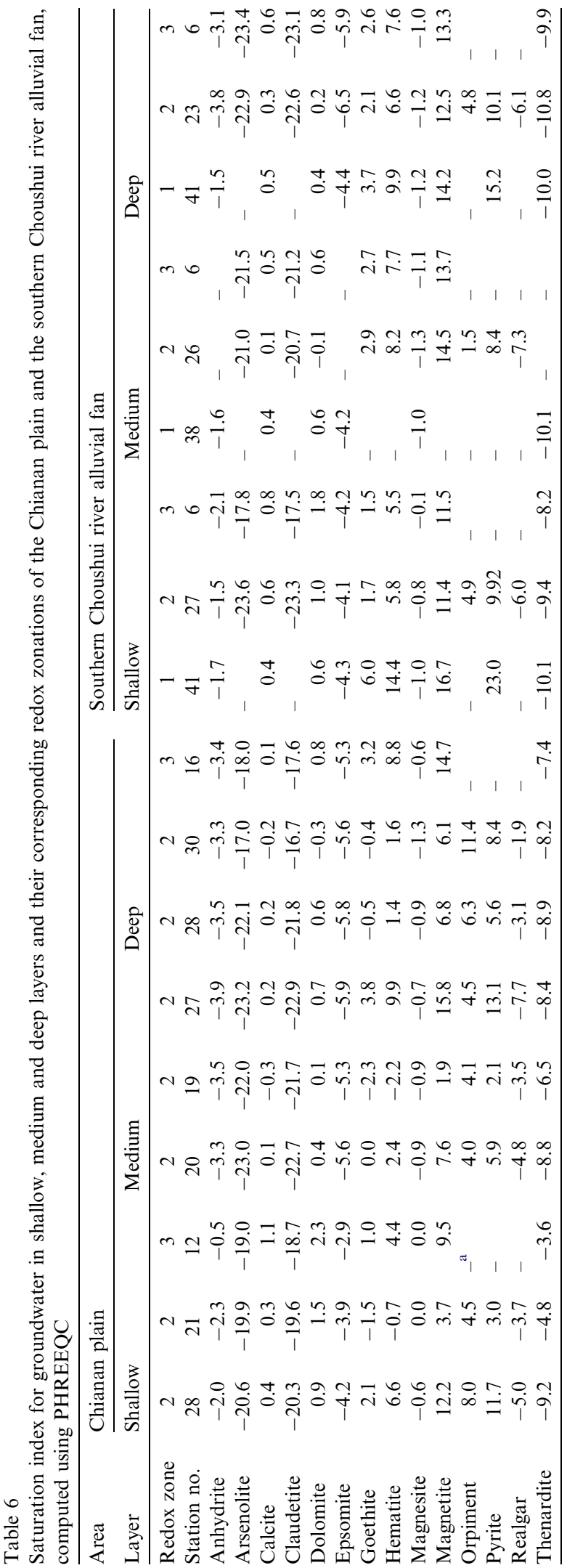

$\mathrm{Fe}(\mathrm{II})$ concentrations indistinctly increase along the flow path of the groundwater, and the $\mathrm{SO}_{4}^{2-}$ concentrations decrease from zone 1 to zones 2 and 3 . However, the concentrations of sulfide are low and do not increase along the flow path (Table 1). High concentrations of $\mathrm{SO}_{4}^{2-}$ in groundwater, hence, may be caused by seawater intrusion, which is one of the important characteristics of this groundwater. The abundant recharge of the mountain area (zone 1) of the southern Choushui river alluvial fan results in the concentrations of dissolved $\mathrm{O}_{2}$ of the shallow and medium layers being higher than other zones. The As concentrations of this recharge area are the lowest of these two catchments. Due to the formation of clayey and confined aquifers in the distal-fan and the mid-fan areas, the reducing tendency and the As concentrations are stronger and higher than those of the mountain area, though the As concentrations of these areas are still lower than those of the Chianan plain.

The average velocity of groundwater flow is about 225, 142 and $56 \mathrm{~m} / \mathrm{a}$ in the proximal-fan, the mid-fan and the distal-fan of the Choushui river alluvial fan (Chinese Society of Agricultural Engineers, 1999), respectively, whereas it is about $1-10 \mathrm{~m} / \mathrm{a}$ in the Chianan plain (Liu, 1999). Chen (2003) and $\mathrm{Lu}$ (2006) indicated that amorphous $\mathrm{Fe}$ oxy-hydroxides are the primary minerals of some core samples, which have high As contents, from the Chianan plain and the coastal area of the southern Choushui river alluvial fan, respectively. Sulfidereducing bacteria were even found in the deep layer of the Chianan plain under the reducing conditions, causing by slow groundwater flow and frequent intercalation of clay and fine-grained sand layers (Chen, 2004). According to the probable mechanisms for As mobility in ground waters of West Bengal and Bangladesh (Bose and Sharma, 2002; Mahimairaja et al., 2005), the dissolution of As-rich Fe oxy-hydroxides due to the onset of reducing conditions in the subsurface is responsible for the mobility of As in groundwater. Under reducing conditions, this process hence may be the primary mechanism of As release to groundwater of the Chianan plain and the southern Choushui river alluvial fan of Taiwan.

\section{Conclusions}

The As-affected groundwater of the Chianan plain was characterized by factor analysis and redox zonation. Factors 1 and 2 in the Chianan plain, the 

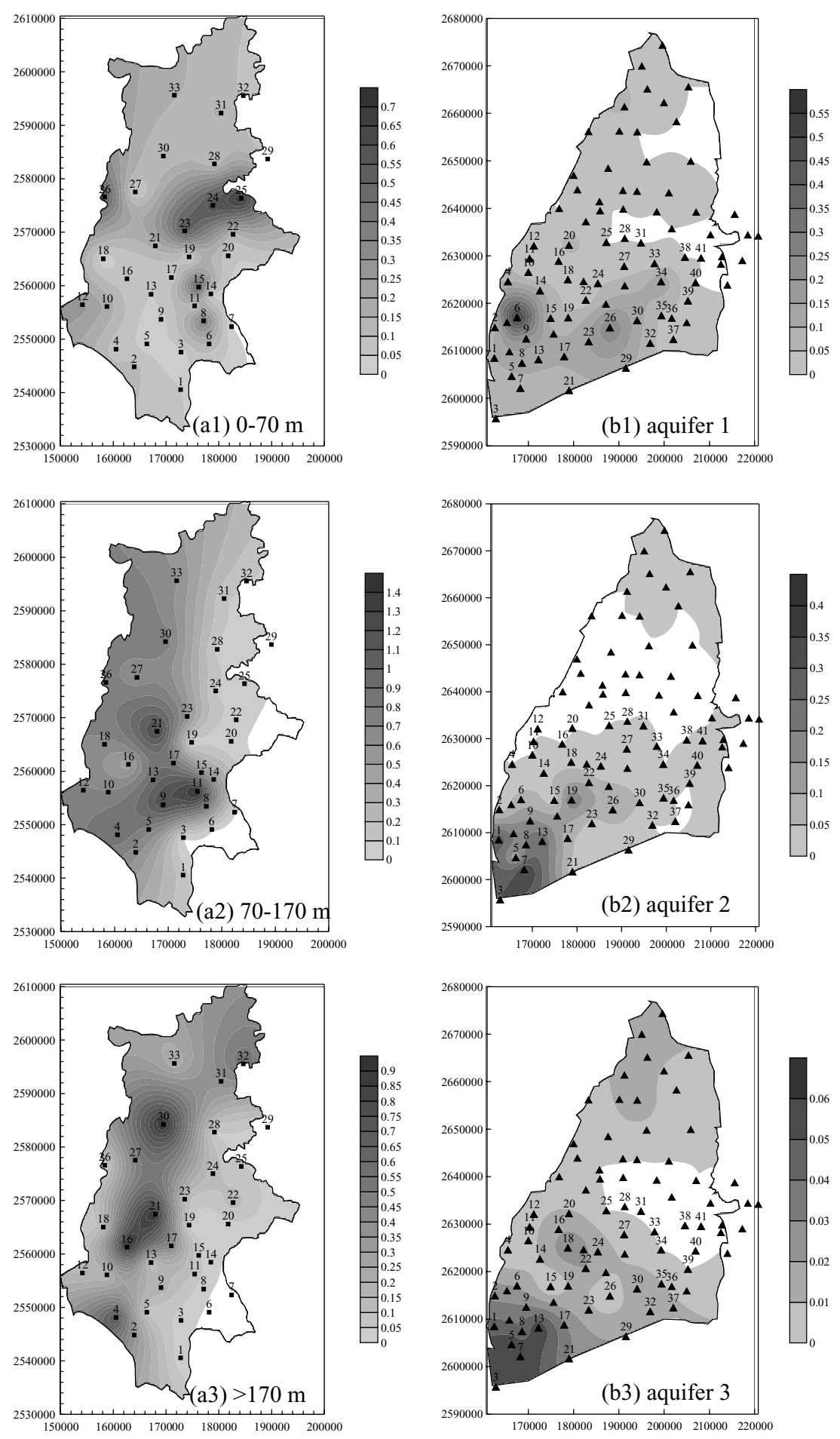

Fig. 6. Arsenic (mg/L) distribution of groundwater at different depths beneath (a) the Chianan plain and (b) the Choushui river alluvial fan.

salinization factor and the As enrichment factor, are similar to those in the southern Choushui river alluvial fan. The manufacture of salt may also be criti- cal to the salinization of the shallow layer of groundwater in the Chianan plain. However, the redox conditions tend to be increasingly reducing 
from the coastal area to the mountainous area in medium and deep layers of the Chianan plain, which trend is a reverse of the Choushui river alluvial fan, where the reducing tendency is from the mountainous area to the coastal area. The different spatial distributions of the redox zonation of these two neighboring areas are dominated by the different hydrogeochemical processes. Furthermore, the reduction potential in the Chianan plain is stronger than that in the Choushui river alluvial fan. The difference between the reduction potentials of these two vicinal catchments affects the concentrations of As in groundwater. The reductive dissolution of As-rich Fe oxyhydroxide seems to be the most probable mechanism of the release of As to groundwater in the Chianan plain and the southern Choushui river alluvial fan. More detailed analyses, such as sequential extraction and synchrotron-based X-ray absorption spectroscopic analyses, will be conducted in the future to confirm the various As release mechanisms in these two groundwater catchments, and to help the local government effectively manage the quality of groundwater resources.

\section{Acknowledgement}

The authors thank the National Science Council of the Republic of China, Taiwan, for financially supporting this research under Contract No. NSC 93-2313-B-002-071.

\section{References}

Anawar, H.M., Akai, J., Komaki, K., Terao, H., Yoshioka, T., Ishizuka, T., Safiullah, S., Kato, K., 2003. Geochemical occurrence of arsenic in groundwater of Bangladesh: sources and mobilization processes. J. Geochem. Explor. 77, 109-131.

Anawar, H.M., Akai, J., Sakugawa, H., 2004. Mobilization of arsenic from subsurface sediments by effect of bicarbonate ions in groundwater. Chemosphere 54, 753-762.

APHA, 1998. Standard Methods for the Examination of Water and Water Waste, 20th ed. American Public Health Association, Washington, DC, 413-426.

Appelo, C.A.J., Van der Weiden, M.J.J., Tournassat, C., Charlet, L., 2002. Surface complexation of ferrous iron and carbonate on ferrihydrite and the mobilization of arsenic. Environ. Sci. Technol. 36, 3096-3103.

Baedecker, M.J., Back, W., 1979a. Modern marine sediments as a natural analog to the chemically stressed environment of a landfill. J. Hydrol. 43, 393-414.

Baedecker, M.J., Back, W., 1979b. Hydrogeological processes and chemical reactions at a landfill. Ground Water 17, 429437.

Bauer, M., Blodau, C., 2006. Mobilization of arsenic by dissolved organic matter from iron oxides, soil and sediments. Sci. Total Environ. 354, 179-190.
Bhattacharya, P., Chatterjee, D., Jacks, G., 1997. Occurrence of arsenic contaminated groundwater in alluvial aquifers from Delta Plains, eastern India: options for safe drinking water supply. Int. J. Water Resour. Dev. 13, 79-92.

Bhattacharya, P., Welch, A.H., Ahmed, K.M., Jacks, G., Naidu, R., 2004. Arsenic in groundwater of sedimentary aquifers. Appl. Geochem. 19, 163-167.

Bose, P., Sharma, A., 2002. Role of iron in controlling speciation and mobilization of arsenic in subsurface environment. Water Resour. 36, 4916-4926.

Central Geological Survey, 1999. Project of Groundwater Monitoring Network in Taiwan during First Stage-Research Report of Chou-Shui River Alluvial Fan, Taiwan. Taiwan Water Resources Bureau.

Chapelle, F.H., Zelibor Jr., J.L., Grimes, D.J., Knobel, L.L., 1987. Bacteria in deep coastal plain sediments of Maryland: a possible source of $\mathrm{CO}_{2}$ to groundwater. Water Resour. Res. 23, 1625-1632.

Chapelle, F.H., McMahon, P.B., Dubrovsky, N.M., Fujii, R.F., Oaksford, E.T., Vroblesky, D.A., 1995. Deducing the distribution of terminal electron-accepting processes in hydrologically diverse groundwater systems. Water Resour. Res. 31, 359-371.

Chatterjee, A.D., Das, D., Mandal, B.K., Chowdhury, T.R., Samanta, G., Chakraborty, D., 1995. Arsenic in groundwater in 6 districts of West Bengal, India - the biggest arsenic calamity in the world. A. Arsenic species in drinking water and urine of the affected people. Analyst 120, 643-650.

Chen, C.C., 2003. Accumulation and Release of Arsenic in Sediments from Hsindong and Jinhu in Chianan Plain, Taiwan. Masters thesis, Department of Geoscience, National Taiwan University, Taipei, Taiwan, ROC.

Chen, Y.T., 2004. Sulfate-reducing Bacteria and Geochemistry of Porewater from Putai Core Sediments in Chianan Plain, Taiwan. Master thesis, Department of Geoscience, National Taiwan University, Taipei, Taiwan, ROC.

Chen, W.F., Liu, T.K., 2003. Dissolved oxygen and nitrate of groundwater in Choushui Fan-Delta, western Taiwan. Environ. Geol. 44, 731-737.

Chen, C.J., Wang, C.J., 1990. Ecological correlation between arsenic levels in well water and aged-adjusted mortality from malignant neoplasms. Cancer Res. 50, 5470-5474.

Chen, C.J., Hsueh, Y.M., Lai, M.S., Shyu, M.P., Chen, S.Y., Wu, M.M., Kuo, T.L., Tai, T.Y., 1995. Increased prevalence of hypertension and long-term arsenic exposure. Hypertension $25,53-60$.

Chinese Society of Agricultural Engineers, 1999. Compilation "Groundwater in Taiwan-Choushuichi Alluvial Plain". Taiwan Water Resource Bureau.

Garcia-Sanchez, A., Moyano, A., Mayorga, P., 2005. High arsenic contents in groundwater of central Spain. Environ. Geol. 47, 847-854.

Han, B.C., Jeng, W.L., Chen, R.Y., Fang, G.T., Hung, T.C., Tseng, R.J., 1998. Estimation of target hazard quotients and potential health risks for metals by consumption of seafood in Taiwan. Arch. Environ. Contam. Toxicol. 35, 711-720.

Harvey, C.F., Swartz, C.H., Badruzzaman, A.B.M., Keon-Blute, N., Yu, W., Ali, M.A., Jay, J., Beckie, R., Niedan, V., Brabander, D., Oates, P.M., Ashfaque, K.N., Islam, S., Hemond, H.F., Ahmed, M.F., 2002. Arsenic mobility and groundwater extraction in Bangladesh. Science 22, 16021606. 
Herbel, M., Fendorf, S., 2006. Biogeochemical processes controlling the speciation and transport of arsenic within iron coated sands. Chem. Geol. 228, 16-32.

Hering, J.G., Chen, P.-Y., Wilkie, J.A., Elimelech, M., 1997. Arsenic removal from drinking water during coagulation. J. Environ. Eng.-ASCE 123, 800-807.

Huang, C.Y., 1996. Foraminiferal analysis and stratigraphic correlation on the subsurface geology of the Choushuichi alluvial fan. In: Proceedings of the Conference on Groundwater and Hydrogeology of Choushui River Alluvial Fan. pp. $55-66$.

Huang, Y.K., Lin, K.H., Chen, H.W., Chang, C.C., Liu, C.W., Yang, M.H., Hsueh, Y.M., 2003. As species contents at aquaculture farm and in farmed mouthbreeder (Oreochromis mossambicus) in BFD hyperendemic areas. Food Chem. Toxicol. 41, 1491-1500.

Jang, C.S., Liu, C.W., 2005. Contamination potential of nitrogen compounds in the heterogeneous aquifers of the Choushui river alluvial fan, Taiwan. J. Contam. Hydrol. 79, $135-155$.

Jang, C.S., Liu, C.W., Lin, K.H., Huang, F.M., Wang, S.W., 2006. Spatial analysis of potential carcinogenic risks associated with ingesting arsenic in aquacultural tilpia (Oreochromis mossambicus) in blackfoot disease hyperendemic areas. Environ. Sci. Technol. 40, 1707-1713.

Kim, M.J., Nriagu, J., Haack, S., 2000. Carbonate ions and arsenic dissolution by groundwater. Environ. Sci. Technol. 34, 3094-3100.

Kuhn, A., Sigg, L., 1993. Arsenic cycling in eutrophic Lake Greifen, Switzerland: influence of seasonal redox processes. Limnol. Oceanog. 38, 1052-1059.

Lai, M.S., Hsueh, Y.M., Chen, C.J., Shyu, M.P., Chen, S.Y., Kuo, T.L., Wu, M.M., Tai, T.Y., 1994. Ingested inorganic arsenic and prevalence of diabetes mellitus. Am. J. Epidemiol. $139,484-492$

Lambrakis, N.J., Voudouris, K.S., Tiniakos, L.N., Kallergis, G.A., 1996. Impacts of simultaneous action of drought and overpumping on quaternary aquifers of glafkos basin (Patras Region, Western Greece). Environ. Geol. 29, 209215.

Liao, C.M., Ling, M.P., 2003. Assessment of human health risks for arsenic bioaccumulation in tilapia (Oreochromis mossambicus) and large-scale mullet (Liza macrolepis) from blackfoot disease area in Taiwan. Arch. Environ. Contam. Toxicol. 45, 264-272.

Liu, T.K., 1999. The Study of Radiocarbon Ages and Vertical Groundwater Quality of the Chianan Plain. Taiwan Water Resource Bureau.

Liu, C.W., Lin, K.H., Kuo, Y.M., 2003. Application of factor analysis in the assessment of groundwater quality in a blackfoot disease area in Taiwan. Sci. Total Environ. 313, 77-89.

Liu, C.W., Huang, F.M., Hsueh, Y.M., 2005. Revised cancer risk assessment of inorganic arsenic upon consumption of tilapia (Oreochromis mossambicus) from blackfoot disease hyperendemic areas. Bull. Environ. Contam. Toxicol. 74, 1037-1044.

Liu, C.W., Wang, S.W., Jang, C.S., Lin, K.H., 2006. Occurrence of arsenic in ground water in the Choushui river alluvial fan, Taiwan. J. Environ. Qual. 35, 68-75.

Loeppert, R.H., 1997. Arsenate, arsenite retention and release in oxide and sulfide dominated systems. Technical Report No.
176, Texas Water Resources Institute, College Station, TX, USA.

Lu, K.L., 2006. The Study of Arsenic Release Mechanisms from Geogenic Deposits of the Choushui River Alluvial Fan, Taiwan. Master thesis, Department of Bioenvironmental Systems Engineering, National Taiwan University, Taipei, Taiwan, ROC.

Mahimairaja, S., Bolan, N.S., Adriano, D.C., Robinson, B., 2005. Arsenic contamination and its risk management in complex environmental settings. Adv. Agron. 86, 1-82.

Mandal, B.K., Chowdhury, T.R., Samanta, G., Basu, G.K., Chowdhury, P.P., Chanda, C.R., Lodh, D., Karan, N.K., Dhar, R.K., Tamili, D.K., Das, D., Saha, K.C., Chakraborti, D., 1996. Arsenic in groundwater in seven districts of West Bengal, India the biggest arsenic calamity in the world. Curr. Sci. 70, 976-986.

McArthur, J.M., Ravenscroft, P., Safiullah, S., Thirlwall, M.F., 2001. Arsenic in groundwater: testing pollution mechanisms for sedimentary aquifers in Bangladesh. Water Resour. Res. 37, 109-117.

Nicholas, D.R., Ramamoorthy, S., Palace, V., Spring, S., Moore, J.N., Rosenzweig, R.F., 2003. Biogeochemical transformations of arsenic in circumneutral freshwater sediments. Biodegradation 14, 123-137.

Nickson, R., McArthur, J., Burgess, W., Ahmed, K.M., Ravenscroft, P., Rahman, M., 1998. Arsenic poisoning of Bangladesh groundwater. Nature 395, 338.

Nickson, R.T., McArthur, J.M., Ravenscroft, P., Burgess, W.G., Ahmed, K.M., 2000. Mechanism of arsenic release to groundwater, Bangladesh and West Bengal. Appl. Geochem. 15, 403-413.

Parkhurst, D.L., 1995. User's guide to PHREEQC, A computer model for speciation, reaction-path, advective-transport and inverse geochemical calculations. US Geological Survey Water-Resources Investigation Report, pp. 41954227.

Petalas, C., Lambrakis, N., 2006. Simulation of untense salinization phenomena in coastal aquifers - the case of the coastal aquifers of Thrace. J. Hydrol. 324, 51-64.

Polizzotto, M.L., Harvey, C.F., Sutton, S.R., Fendorf, S., 2005. Processes conducive to the release and transport of arsenic into aquifers of Bangladesh. Proc. Natl. Acad. Sci. USA 102, 18819-18823.

Reyment, R.A., Joreskog, KH., 1993. Applied Factor Analysis in the Natural Sciences. Cambridge University Press, New York, USA.

Spliethoff, H.M., Mason, R.P., Hemond, H.F., 1995. Interannual variability in the speciation and mobility of arsenic in a dimictic lake. Environ. Sci. Technol. 29, 2157-2161.

SPSS Inc., 1998. SPSS BASE 8.0 - Application Guide. SPSS Inc., Chicago, USA.

Stumm, W., Morgan, J.J., 1981. Aquatic Chemistry, second ed. Wiley, New York.

Swartz, C.H., Blute, N.K., Badruzzman, B., Ali, A., Brabander, D., Jay, J., Besancon, J., Islam, S., Hemond, H.F., Harvey, C.F., 2004. Mobility of arsenic in a Bangladesh aquifer: inferences from geochemical profiles, leaching data and mineralogical characterization. Geochim. Cosmochim. Acta 68, 4539-4557.

Taiwan Sugar Company, 1997. Establishment and Operational Management of Groundwater Monitoring Network. Taiwan Water Resource Bureau. 
Taiwan Sugar Company, 2002. Groundwater Quality by the Taiwan Groundwater Monitoring Network (4/5). Taiwan Water Resource Bureau.

Taiwan Sugar Company, 2003. Groundwater Quality by the Taiwan Groundwater Monitoring Network (5/5). Taiwan Water Resource Bureau.

Taiwan Sugar Company, 2004. Groundwater Quality by the Taiwan Groundwater Monitoring Network (1/2). Taiwan Water Resource Bureau.

Tseng, W.P., 1977. Effects and dose-response relationship of skin cancer and Blackfoot disease with arsenic. Environ. Health Perspect 19, 109-119.

Tseng, W.P., 1985. Blackfoot disease and skin cancer in an endemic area of chronic arsenicism in Taiwan. In: Proceedings of the Seminar on Environmental Toxicology, Taipei, 26 March to 2 April, 1985, pp. 142-155.

Tseng, W.P., Chen, W.Y., Sung, J.L., Chen, J.S., 1961. A Clinical Study of Blackfoot Disease in Taiwan, An Endemic Peripheral Vascular Disease. Memoire College Med., National Taiwan University, vol. 7, pp. 1-18.
Villalobos, M., Trotz, M.A., Leckie, J.O., 2001. Surface complexation modeling of carbonate effects on the adsorption of $\mathrm{Cr}(\mathrm{VI}), \mathrm{Pb}-(\mathrm{II})$, and U(VI) on goethite. Environ. Sci. Technol. 35, 3849-3856.

Vink, B.W., 1996. Stability relations of antimony and arsenic compounds in the light of revised and extended Eh-pH diagrams. Chem. Geol. 130, 21-30.

Wilkie, J.A., Hering, J.G., 1996. Adsorption of arsenic onto hydrous ferric oxide: effects of adsorbate/adsorbent ratios and co-occurring solutes. Colloid Surf. A-Physicochem. Eng. Asp. 107, 97-110.

Wu, M.M., Kuo, T.L., Hwang, Y.H., Chen, C.J., 1989. Doseresponse relation between arsenic concentration in well water and mortality from cancers and vascular diseases. Am. J. Epidemiol. 130, 1123-1132.

Zheng, Y., Stute, M., van Geen, A., Gavrieli, I., Dhar, R., Simpson, H.J., Schlosser, P., Ahmed, K.M., 2004. Redox control of arsenic mobilization in Bangladesh groundwater. Appl. Geochem. 19, 201-214. 